\title{
STUDY ON GENETIC VARIATION AND RELATIONSHIPS AMONG FOUR ACACIA SPECIES USING RAPD AND SSCP MARKER
}

\author{
Anthonius Y.P.B.C. Widyatmoko ${ }^{1,2}$, Atsushi Watanabe ${ }^{3}$, and Susumu Shiraishi ${ }^{4}$
}

\begin{abstract}
Genetic diversity and relationship of four Acacia species, Acacia aulacocarpa, A. Cunn. ex Benth., A. auriculiformis Cunn. ex Benth., A. crassicarpa Cunn. ex Benth. and A. mangium Willd. were investigated using DNA molecular markers. Using RAPD analysis, a total of 20 arbitrary primers successfully gave 127 polymorphic fragments. These RAPD data were used to estimate genetic distance and construct dendrograms using the unweighted pair-group with the arithmetic mean average (UPGMA) method. The four species were divided into two major clusters. $A$. auriculiformis and $A$. mangium were in one cluster, and the other cluster contained both $A$. aulacocarpa and $A$. crassicarpa. The divergence time of the two species ( $A$. auriculiformis and $A$. mangium) in the former cluster appeared to be relatively early in comparison to in the latter (A. aulacocarpa and $A$. crassicarpa) based on RAPD data. This result was also supported by Principal Component Analysis (PCA). Among the four species, A. aulacocarpa showed the highest divergence in nuclear DNA (ncDNA), followed by $A$. auriculiformis. SSCP analysis also revealed that these two species possessed a haplotypic variation of the $\operatorname{trn} \mathrm{L}$-trn $\mathrm{F}$ intergenic spacer region of chloroplast DNA. In $A$. aulacocarpa, a large difference in the composition of both nuclear and chloroplast genomes was observed between populations distributed in Queensland, Australia and those in New Guinea Island. In contrast, compared to the other species, $A$. mangium showed the lowest genetic diversity and less genetic differentiation among populations.
\end{abstract}

Keywords: Acacia, genetic variation, phylogeny, RAPD, SSCP

\section{INTRODUCTION}

The genus Acacia is the largest genus of subfamily Mimosoideae, family Leguminosae. It includes over 1,200 species widely distributed in the Southern hemisphere, extending from South America and Australia to Africa (Ross, 1981; Brain and Maslin, 1996; Harrier et al., 1997). The most species-divergence of this genus occurs in Australia where there are approximately 650 species distributed across the continent (Pettigrew and Watson, 1975; Ross, 1981; Boughton, 1986).

\footnotetext{
${ }^{1}$ Center for Forest Biotechnology and Tree Improvement Research, Jl. Palagan Tentara Pelajar Km.15, Purwobinangun, Pakem, Sleman, Yogyakarta, Indonesia.

${ }^{2}$ Corresponding Author. E-mail: aviwicaksono@yahoo.com

${ }^{3}$ Forest Tree Breeding Center, Ibaraki, Japan

${ }^{4}$ Laboratory of Silviculture, Faculty of Agriculture, Kyushu University, Fukuoka, Japan
} 
Acacia auriculiformis A. Cunn. ex Benth. and A. mangium Willd., which belong to section Juliflorae (Benth.) Maiden \& Betche in the subgenus Phyllodineae Benth., are naturally distributed throughout Australia, New Guinea Island, Aru Island, and Sula Island. These species have been introduced as multiple-purpose species for plantation in tropical and subtropical areas around the world. In Southeast Asia, more than 500,000 ha of $A$. mangium plantations have been established for pulp and paper production (Butcher $e$ t al., 1998). Likewise, in Zaire, the plantations of $A$. auriculiformis and $A$. mangium play an important role in providing sufficient fuel wood (Khasa, 1994). In Indonesia, $A$. mangium is the one of the major fast growing species used in plantation forestry program. A. crassicarpa is also become an important fast growing species for plantation in peat land.

Studies of the genetic diversity of the Acacia species have been reported by a number of authors. The genetic diversity of both $A$. auriculiformis and $A$. mangium has been assessed using isozyme analysis (Moran et al., 1988, 1989; Wickneswari and Norwati, 1993; Khasa, 1993, 1994). Moran et al. (1988) compared the genetic diversity of nine Acacia species based on isozyme analysis. The genetic diversity of $A$. mangium has also been studied using RFLP (restriction fragment length polymorphism) markers (Butcher et al., 1998).

Studies of the taxonomy and phylogeny of genus Acacia have been reported based on biochemistry and DNA molecular markers. Due to a serological investigation, Brain and Maslin (1996) have estimated the classification of 48 species of subgenus Phyllodineae, predominantly distributed in Australia. In addition, Harrier et al. (1997) have performed RAPD (random amplified polymorphic DNA) analysis to assess the phylogenetic relationship of African Acacia species.

Recently, various DNA molecular markers have been used to infer phylogenetic hypotheses at numerous taxonomic levels. One method that has been utilized for various applications employs the RAPD marker (Williams et al., 1990) and can simply and rapidly provide information regarding the nuclear genome. RAPD analysis has been used to elucidate phylogeny at lower taxonomic levels (Das et al., 2001) and population genetics and genetic diversity studies (Rimbawanto and Widyatmoko, 2006; Rimbawanto et al., 2006a; Rimbawanto et al., 2006b; Wang et al., 2006). PCRSSCP is another rapid and sensitive marker especially for exploring point mutations and sequence polymorphisms. This marker is advantageous for detecting small DNA changes such as single base substitutions, deletions and insertions at various positions in DNA fragments (Orita et al., 1989). It has been applied for the investigation of inheritance and molecular variation (Bodenes et al., 1996; Caron et al., 2000; Shiraishi et al., 2001; Chen et al., 2002).

Our study approached the phylogenetic questions of four Acacia species, i.e. $A$. aulacocarpa, A. crassicarpa, A. auriculiformis, and A. mangium, based on the information derived from the RAPD analysis of nuclear DNA and SSCP (single strand conformation 
polymorphism) analysis of chloroplast DNA. Further, we preliminarily estimated the genetic diversity of the four Acacia species.

\section{MATERIALS AND METHODS}

\section{A. Plant materials and DNA extraction}

Seeds of the four species were obtained from the Australian Tree Seed Centre of CSIRO (Commonwealth Scientific and Industrial Research Organization), Australia and Forest Tree Improvement Research and Development Institute, Indonesia.

In order to elucidate the phylogeny among the four species and their genetic diversity, six seeds per species were used (Table 1). For A. aulacocarpa, one seed from Indonesia (IND), two from Papua New Guinea (PNG), and three from Queensland (QLD) were used. For $A$. auriculiformis, two seeds from PNG, three from QLD, and one from the Northern Territory (NT) were used. For A.crassicarpa and A.mangium, two seeds were used for each region (IND, PNG and QLD). These samples represented the natural distribution of each species. The approximate location of each sample of the four species is shown in Figure 1.

To examine the genetic diversity of $A$. mangium in more detail, seed samples were further added from two populations in IND, PNG, and QLD, respectively (Table 2). Except for Piru of the Ceram Island, four seeds of different seedlots were used for each population. For Piru, four seeds from one bulk seedlot were used.

Total genomic DNA was extracted using a modified CTAB protocol reported by Shiraishi and Watanabe (1995). The DNA was purified using GENECLEAN III (BIO101) as a template for further analyses.

\section{B. RAPD analysis}

RAPD analysis was performed in a reaction containing $10 \mathrm{mM}$ Tris- $\mathrm{HCl}(\mathrm{pH} 8.3)$, $10 \mathrm{mM} \mathrm{KCl}, 3.0 \mathrm{mM} \mathrm{MgCl}, 0.2 \mathrm{mM}$ each of dNTPs, 0.5 unit/10 $\mu$ l AmpliTaq DNA polymerase, a Stoffel fragment (Perkin-Elmer), $0.25 \mu \mathrm{M}$ each of primers, and $10 \mathrm{ng} / 10 \mu \mathrm{l}$ template DNA. The condition of amplification was $94^{\circ} \mathrm{C}$ for $1 \mathrm{~min}$., 45 cycles of $30 \mathrm{~s}$ at $94^{\circ} \mathrm{C}, 30 \mathrm{~s}$ at $37^{\circ} \mathrm{C}$, and $90 \mathrm{~s}$ at $72^{\circ} \mathrm{C}$, followed by $7 \mathrm{~min}$. at $72^{\circ} \mathrm{C}$. The amplification products were separated by electrophoresis in $1 \%$ agarose gel with ethidium bromide and detected with a 302-nm UV transilluminator. 
Table 1. Details of samples of four Acacia species and their cpDNA haplotypes

\begin{tabular}{|c|c|c|c|c|c|}
\hline \multirow{2}{*}{$\begin{array}{c}\text { Species } \\
\text { Acacia aulacocarpa }\end{array}$} & \multirow{2}{*}{$\begin{array}{c}\text { No. } \\
\text { AL } 1\end{array}$} & \multicolumn{2}{|l|}{$\begin{array}{c}\text { Seed source } \\
\text { (Territory /Nation) }\end{array}$} & \multirow{2}{*}{$\begin{array}{r}\text { Seedlot No. } \\
\text { AL-1001 }\end{array}$} & \multirow{2}{*}{$\begin{array}{c}\text { CpDNA } \\
\text { SSCP } \\
\text { type }\end{array}$} \\
\hline & & Kuel, Irian Jaya & (IND) & & \\
\hline & AL 2 & Makapa WP & $(\mathrm{PNG})$ & 16947-M 0000003 & I \\
\hline & AL 3 & Balimo District & $(\mathrm{PNG})$ & 16946-AK 000001 & I \\
\hline & AL 4 & Old Rock Hart Airstrip & (QLD) & 18358-GJM 1377 & III \\
\hline & AL 5 & 10K NW. Mt. Molloy & (QLD) & 17891-GB 000096 & III \\
\hline & AL 6 & Samford & (QLD) & 17905-TREE 1 & II \\
\hline \multirow[t]{6}{*}{ Acacia auriculiformis } & AR 1 & Morehead R Rouku WP & $(\mathrm{PNG})$ & 16606-BVG 01220 & IV \\
\hline & AR 2 & Bensbach WP & $(\mathrm{PNG})$ & 17553-KN 000011 & $\mathrm{~V}$ \\
\hline & AR 3 & (R) Orchard Melville Is. & (NT) & $18601-6$ & VI \\
\hline & AR 4 & Lower Poscoe River & (QLD) & 18359-MHL 20 & IV \\
\hline & AR 5 & Boggy Creek & (QLD) & 17966-BН 14061 & IV \\
\hline & AR 6 & E Normamby River & (QLD) & 16756-BG 004936 & IV \\
\hline \multirow[t]{6}{*}{ Acacia crassicarpa } & AC 1 & Kuel, Irian Jaya & (IND) & $\mathrm{AC}-1107^{* *}$ & III \\
\hline & $\mathrm{AC} 2$ & Wasur, Irian Jaya & (IND) & AC- $1001^{* *}$ & III \\
\hline & AC 3 & Gubam Village WP & $(\mathrm{PNG})$ & 16597-BVG 01100 & III \\
\hline & AC 4 & Wemenever Prov & $(\mathrm{PNG})$ & 13680-JC 001503 & III \\
\hline & AC 5 & Claudie River & (QLD) & 17944-MHL 04 & III \\
\hline & AC 6 & Parish of Annan & $(\mathrm{QLD})$ & 16775-ВН 013582 & III \\
\hline \multirow[t]{6}{*}{ Acacia mangium } & $\mathrm{AM} 1$ & Piru, Seram & (IND) & AM- $570^{*}$ & VI \\
\hline & AM 2 & Kuel, Irian Jaya & (IND) & AM- $1001^{* *}$ & VI \\
\hline & AM 3 & Gubam Ne Morehead WP & $(\mathrm{PNG})$ & 16991-BVG 01547 & VI \\
\hline & $\mathrm{AM} 4$ & Wipim District WP & $(\mathrm{PNG})$ & 16971-BVG 01626 & VI \\
\hline & AM 5 & Claudie River & (QLD) & 17946-GJM 1110 & VI \\
\hline & AM 6 & Tully-Mission Beach & (QLD) & 17703-GLM 00920 & VI \\
\hline
\end{tabular}




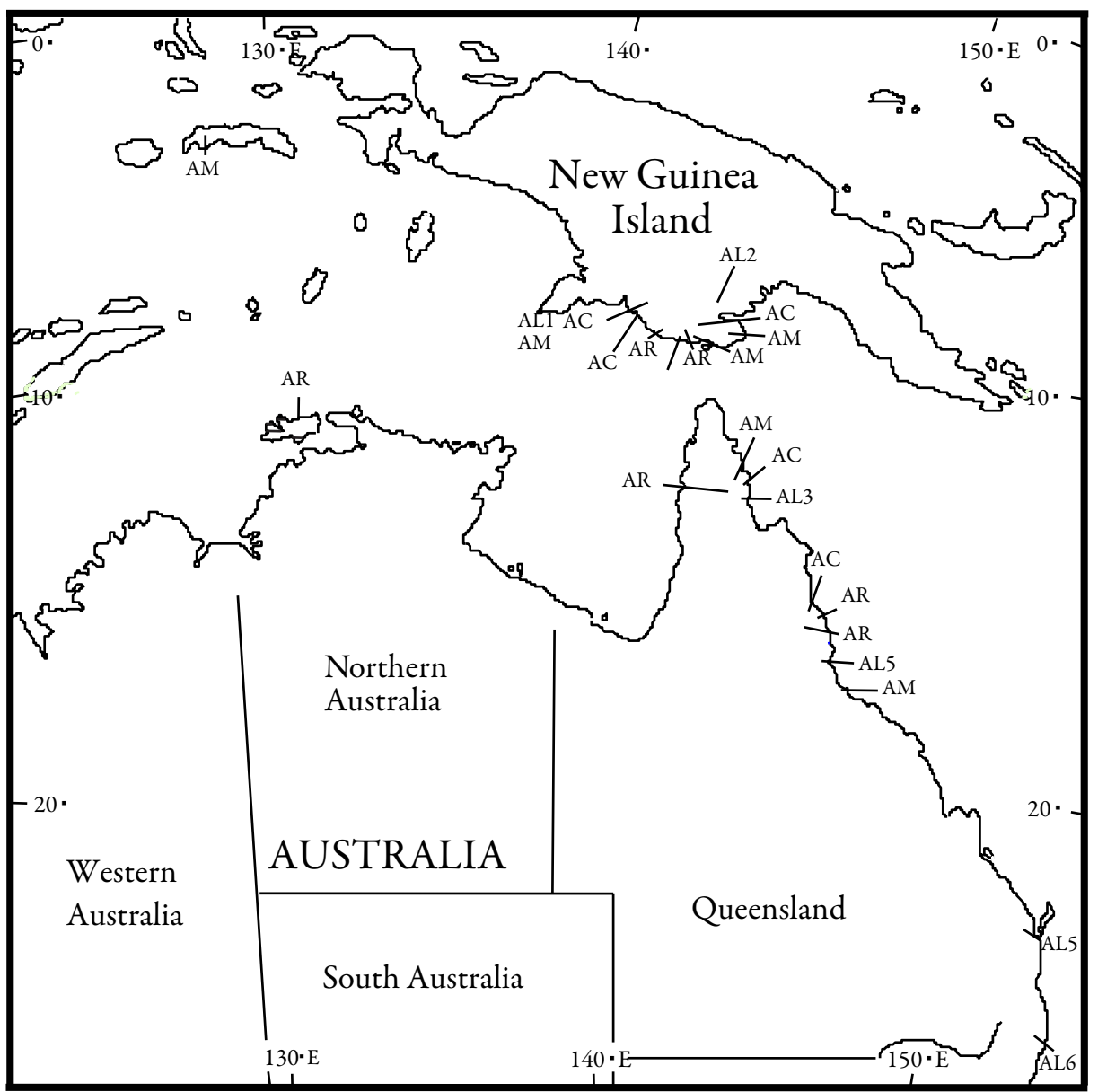

Figure 1. Approximate location of four species samples

Twenty useful primers were selected in a preliminary primer screening and used in the RAPD analysis of this study (Table 3). Among the 20 primers, 15 primers were from Operon Technologies. The sequences of the other five primers were, FB-02: 5'-CAGTTCTGGC-3', FB-05: 5'-ACTCGTAGCC-3' (Shiraishi et al., 1996), FB-03: 5'-CCTGGCGAGC-3' (Narazaki et al., 1996), FB-08: 5'-CGACAAGCTC-3', and FB-09: 5'-CTCGGTGATC-3'. In order to produce reliable data, DNA samples for the RAPD analysis were randomized (Figure 2) and a sample-blind analysis was carried out. 
Table 2. Details of samples of Acacia mangium (AM)

\begin{tabular}{|c|c|c|}
\hline Seed source (population) & Code & Seedlot No. \\
\hline Piru, Seram (IND) & PS & $\begin{array}{l}\text { AM- } 570^{*} \\
\text { AM- } 570^{*} \\
\text { AM- } 570^{*} \\
\text { AM- } 570^{*}\end{array}$ \\
\hline Kuel, Irian Jaya (IND) & KI & $\begin{array}{l}\text { AM-1001** } \\
\text { AM-1002** } \\
\text { AM-1003** } \\
\text { AM-1004** }\end{array}$ \\
\hline Gubam Ne Morehead WP (PNG) & GM & $\begin{array}{l}\text { 16991-BVG } 01547 \\
\text { 16991-GUB } 00012 \\
\text { 16991-GUB } 00004 \\
\text { 16991-BVG } 01541\end{array}$ \\
\hline Wipim District WP (PNG) & WD & $\begin{array}{l}\text { 16971-BVG } 01626 \\
\text { 16971-BVG } 01595 \\
\text { 16971-BVG } 01588 \\
16971-B V G 01625\end{array}$ \\
\hline Claudie River (QLD) & CR & $\begin{array}{l}\text { 17946-GJM } 1110 \\
\text { 17946-GJM } 1373 \\
\text { 17946-GJM } 1097 \\
\text { 17946-GJM } 1120\end{array}$ \\
\hline Tully-Mission Beach (QLD) & TB & $\begin{array}{l}\text { 17703-GJM } 00920 \\
17703-G J M 00926 \\
17703-G J M 00933 \\
17703-G J M 00939\end{array}$ \\
\hline
\end{tabular}

Notes: ${ }^{*, * *}$ The seeds were collected by the Forest Tree Improvement Research and Development Institute, Yogyakarta, Indonesia ( ${ }^{*}$ bulked; ${ }^{* *}$ individual)

The other seeds were collected by Australia Tree Seed Centre, CSIRO, Australia IND, Indonesia; PNG, Papua New Guinea; QLD, Queensland, Australia 
Table 3. RAPD primers used in this study

\begin{tabular}{clll}
\hline No. & Primer & No. & Primer \\
\hline 1 & OPA-06 & 11 & OPK-16 \\
2 & OPA-08 & 12 & OPN-07 \\
3 & OPA-17 & 13 & OPO-13 \\
4 & OPA-18 & 14 & OPS-10 \\
5 & OPB-06 & 15 & OPS-18 \\
6 & OPC-02 & 16 & FB-2 \\
7 & OPC-11 & 17 & FB-3* \\
8 & OPJ-13 & 18 & FB-5* \\
9 & OPJ-18 & 19 & FB-9* \\
10 & OPK-02 & 20 & FB-8 \\
\hline
\end{tabular}

Note: ${ }^{*}$ These primers were synthesized by our laboratory.

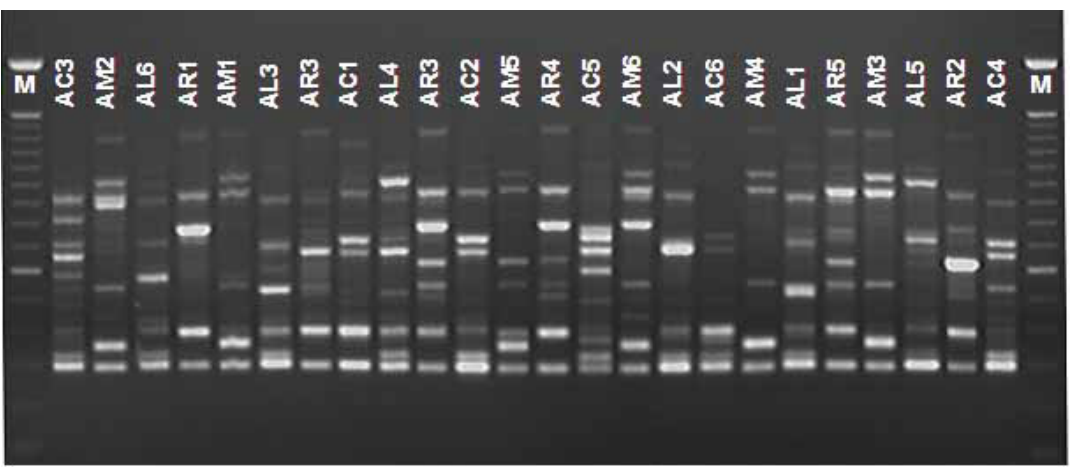

Figure 2. Example of RAPD profile of four Acacia species using primer FB-02.

Number of each lane according to Table 1

The presence (1) or absence (0) of the polymorphic fragments attained from electrophoresis was noted as $1 / 0$ data. Based on this data, the genetic similarity $(S)$ and genetic distance $(D=1-S)$ among all individuals were calculated using a simple matching coefficient (Sokal and Michener, 1958). A dendrogram was constructed using the UPGMA method from the matrix of genetic distance among individuals (using POPGEN software program). A Principal Component Analysis was also performed to compare genome information between the species. 


\section{SSCP analysis}

In order to investigate a chloroplast DNA haplotype variation, an SSCP analysis of the intergenic spacer region between the $\operatorname{trn} \mathrm{P}$ and $\operatorname{trn} \mathrm{W}$ genes was carried out using the newly designed primers (5'-TTGGTAGCGTGTTTGTTTTGGG-3', 5'-TACGGCATCGGTTTTGGAGAC-3'). Except for the primers, the reaction solution and PCR conditions followed previously reported guidelines (Watanabe et al., 1997).

PCR product $(2.5 \mu \mathrm{l})$ was mixed with $12 \mu \mathrm{l}$ of loading buffer (1xTBE, $0.25 \%$ bromophenol blue, $77 \%$ formamide). After the solution was concentrated for $15 \mathrm{~min}$. using the vacuum evaporator, it was denatured for $5 \mathrm{~min}$. at $94^{\circ} \mathrm{C}$ and then immediately cooled on ice. For electrophoresis, this sample was loaded into $7 \%$ polyacrylamide gel (39: 1 acrylamide to bis acrylamide) with $1 x$ TBE buffer. The electrophoresis was run at $1.5 \mathrm{~V} / \mathrm{cm}, 10^{\circ} \mathrm{C}$. After electrophoresis, the gel was stained for $15 \mathrm{~min}$. in a staining solution (1xTBE, $0.5 \mu \mathrm{g} / \mathrm{ml}$ ethidium bromide) and visualized using a 302-nm UV transilluminator.

\section{RESULTS}

\section{A. RAPD analysis of four Acacia species}

In the RAPD analysis, the informative polymorphic fragments were amplified in a range from 200 to 1,400 bps, with most being located between 400 and 800 bps. A total of 127 polymorphic fragments were scored for the 20 primers in the 24 individuals of the four species. The FB-02 primer amplified the maximum number of polymorphic fragments (10 fragments). The mean number per primer was 6.4.

The polymorphic fragment rate, which differed widely among the species, is shown in Table 3. Of 127 fragments, $A$. aulacocarpa had 55 polymorphic fragments, and its polymorphic rate was the highest (0.43); that of $A$. auriculiformis was the second highest $(0.31)$. In contrast, $A$. mangium had only 24 polymorphic fragments out of all fragments. This value was less than the half that of $A$. aulacocarpa.

Furthermore, based on the 1/0 data of 127 polymorphic fragments, the genetic distances between the individuals were derived from a simple matching coefficient. The mean genetic distances within and between species are given in Table 5 . The mean genetic distance between individuals of $A$. aulacocarpa was $0.20 \pm 0.09$. For the other species, $A$. auriculiformis, $A$.crassicarpa, and $A$. mangium, the distances were $0.13 \pm 0.05$, $0.10 \pm 0.05$, and $0.08 \pm 0.02$, respectively.

In order to clarify the relationship among species, a UPGMA dendrogram was constructed from these genetic distances (Figure 3), and two distinct clusters were identified. The first cluster comprised $A$. auriculiformis and $A$. mangium, and the remaining two species, $A$. aulacocarpa and $A$. crassicarpa formed the other cluster. The 
genetic distances between the two clusters were $0.49-0.63(0.56 \pm 0.10)$. These results suggest that the two clusters can be phylogenetically separated.

Table 4. Number of RAPD fragments obtained in each species and the ratio of polymorphic fragments

\begin{tabular}{lccc}
\hline \multicolumn{1}{c}{ Species } & $\begin{array}{c}\text { Number of } \\
\text { polymorphic fragments }\end{array}$ & $\begin{array}{c}\text { Number of } \\
\text { monomorphic } \\
\text { fragments }\end{array}$ & $\begin{array}{c}\text { Ratio of } \\
\text { polymorphic fragments }\end{array}$ \\
\hline A. aulacocarpa & 55 & 74 & 0.43 \\
A. auriculiformis & 39 & 88 & 0.31 \\
A. crassicarpa & 30 & 97 & 0.24 \\
A. mangium & 24 & 103 & 0.19 \\
\hline
\end{tabular}

$A$. auriculiformis and $A$. mangium were grouped into a monophyletic group. The divergence between both species is represented by a long branch, and they diverged in relatively earlier time. The genetic distance between the two species was $0.4 \pm 0.02$, and the difference in the genome formation of each species can be clearly identified.

Table 5. Mean genetic distances between and within four Acacia species

\begin{tabular}{ccccc}
\hline Species & AL & AR & AC & AM \\
\hline A. aulacocarpa (AL) & $0.20 \pm 0.09^{*}$ & & & \\
A. auriculiformis (AR) & $0.49 \pm 0.06$ & $0.13 \pm 0.05$ & & \\
A. crassicarpa (AC & & & & \\
A. mangium (AM) & $0.23 \pm 0.05$ & $0.52 \pm 0.05$ & $0.10 \pm 0.05$ & \\
& $0.59 \pm 0.05$ & $0.40 \pm 0.05$ & $0.63 \pm 0.07$ & $0.08 \pm 0.02$ \\
\hline
\end{tabular}

Notes: ${ }^{*}$ mean \pm standard deviation. Diagonal was genetic diversity within species. Below diagonal was genetic distance between species

$A$. aulacocarpa and $A$. crassicarpa were found to be closely related phylogenetically. The difference in genome formation between them was not clear compared with that between $A$. auriculiformis and $A$. mangium. Six samples of $A$. crassicarpa formed a monophyletic group, with the mean genetic distances among them suggesting that the genetic difference within the species was small. In $A$. aulacocarpa, two clusters were observed in Figure 2. One was formed with three individuals from New Guinea Island (NGI: PNG and IND), and the other was represented by three individuals from QLD. 
The mean genetic distance within NGI was $0.11 \pm 0.01$, which was almost the same as the mean genetic distance within $A$. crassicarpa and $A$. mangium. In contrast, a higher value was obtained within QLD $(0.18 \pm 0.01)$. The mean genetic distance between NGI and QLD was $0.24 \pm 0.028$. This species was clearly split into two phylogenetically different groups between New Guinea Island and Australia.

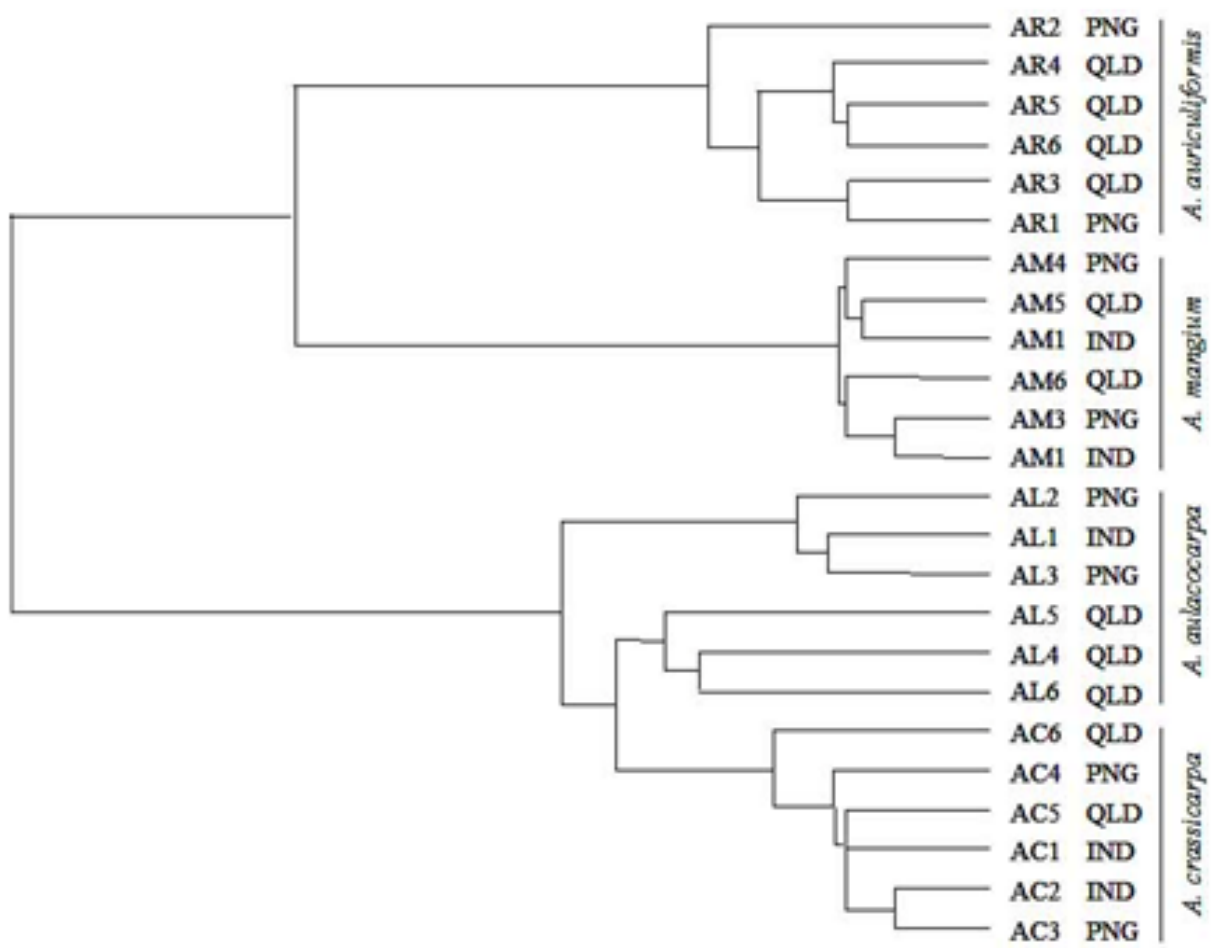

Figure 3. The relationships between four Acacia species. Number of each seed source according to Table 1

The results of the Principal Component Analysis (PCA) are shown in Figure 4. The first three principal components from PCA accounted for $69.6 \%$ of the total variation among samples. The proportions of the principal components one (PC1), two (PC2), and three (PC3) were 41.3\%, 19.5\% and 8.8\%, respectively. In the plot of PC1 and PC2 (Figure 4(A)), 24 samples of the four species are separated into three groups. $A$. auriculiformis and $A$. mangium are clearly separated into different groups, but $A$. aulacocarpa and $A$. crassicarpa are not. In the plot of PC1 and PC3 (Figure 4(B)), $A$. aulacocarpa and $A$. crassicarpa, which are grouped together in Figure 4 (A), are separated into three groups: $A$. aulacocarpa of NGI, $A$. aulacocarpa of QLD, and $A$. crassicarpa. The result of the PCA analysis was similar to that of the UPGMA analysis. 


\section{B. SSCP analysis of cpDNA in four Acacia species}

An SSCP analysis of the intergenic spacer region between the trn $\mathrm{P}$ and $\operatorname{trn} \mathrm{W}$ genes was carried out in order to investigate the chloroplast DNA variation of the four Acacia species (Figure 5 and Table 1 ). In $A$. crassicarpa and $A$. mangium, no variation within species was observed in the six samples. In contrast, an intraspecific cpDNA haplotype polymorphism was recognized in $A$. auriculiformis and $A$. aulacocarpa. In $A$. aulacocarpa, three samples from NGI (AL1, AL2, AL3) confirmed two PCR products (ca. $320 \mathrm{bps}$ and $420 \mathrm{bps}$ ), and three samples from QLD (AL4, AL5, AL6) also confirmed two PCR products (320 bps and $360 \mathrm{bps}$ ), one of which showed a length variation (Figure 5(A)). The SSCP analysis of the PCR products is shown in Figure 5 (B). Three NGI samples (type I) and three QLD samples possessed four bands of single-strand DNA, of which two bands were common and the other two showed a different electrophoretic mobility. Furthermore, of the three QLD samples, there were two different single-strand DNA profiles, one for AL6, type II, and the other for the two type III samples. $A$. aulacocarpa from QLD possessed at least two cpDNA haplotypes. In $A$. auriculiformis, three haplotypes (type IV, V, and VI) were observed. No common haplotype existed between the three types of $A$. aulacocarpa and the three types of $A$. auriculiformis. The chloroplast DNA haplotype appearing in $A$. crassicarpa and $A$. mangium was one of the haplotypes observed in $A$. aulacocarpa and $A$. auriculiformis, respectively.

The SSCP analysis of cpDNA also showed that the genetic diversity of $A$. aulacocarpa is high. A differentiation in cpDNA haplotypes could be recognized between QLD and NGI. The cpDNA information also supported the results of the cluster analysis and PCA of ncDNA. A a auriculiformis, which had high diversity in its ncDNA, also showed an intraspecific polymorphism in its cpDNA.
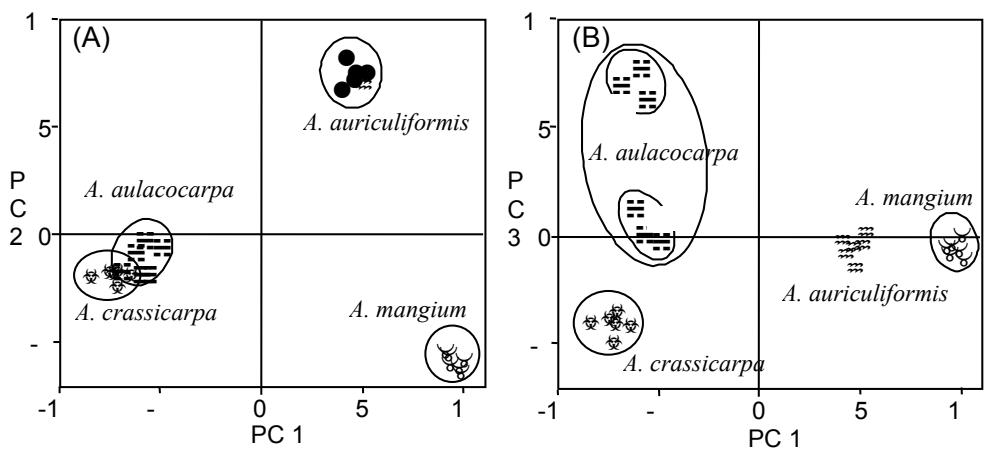

Figure 4. Principal components analysis of RAPD fragments. (A) Plot of the first two principal components. (B) Plot of the first and third principal components. NGI, New Guinea Island; QLD, Queensland 


\section{RAPD analysis of A. mangium}

The RAPD analysis suggested that $A$. mangium possesses the least genetic diversity among the four Acacia species. The genetic diversity of $A$. mangium was confirmed using 24 samples from six populations (four samples per population).

In addition to the experiment to elucidate the phylogeny relationship of the four species, samples for RAPD analysis were also randomized and analyzed with a sampleblind in this experiment. The same primers as those of the former experiment were used in this analysis. The $1 / 0$ of the 127 polymorphic fragments found in the previous experiment was scored in all 24 samples. A RAPD analysis of 24 samples from six populations showed that 24 fragments of 127 fragments were polymorphic and the other 103 were monomorphic, which was in agreement with previous results (Table 4).

The mean genetic distances within and between populations calculated using a simple matching coefficient are shown in Table 6. The genetic distances between samples were from 0.03 to $0.09(0.07 \pm 0.02)$, a result that is not significantly different from that estimated from the six samples in the previous experiment $(0.08 \pm 0.02)$.

$\begin{array}{lllllllllllll}M & \text { AL1 AL6 AL4 AR1 AR2 AR3 AC1 AC3 AC6 AM1 AM2 AM5 }\end{array}$

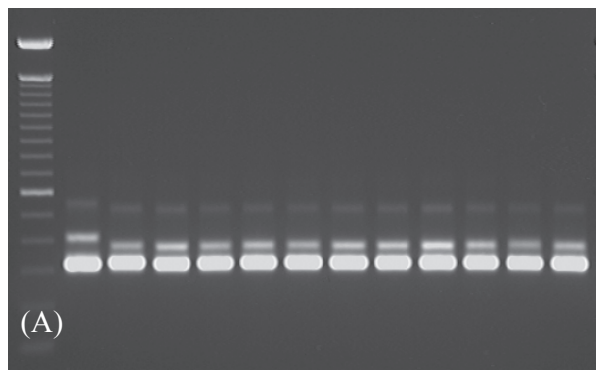

AL1 AL6 AL4 AR1 AR2 AR3 AC1 AC3 AC6 AM1 AM2 AM5

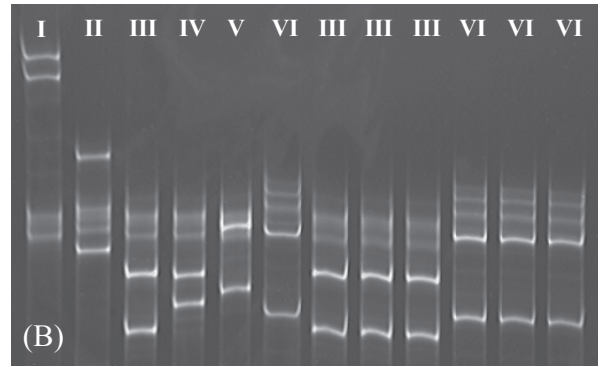

Figure 5. PCR (A) and Cold SSCP (B) profiles of the chloroplast intergenic spacer between $\operatorname{trn} \mathrm{P}$ and $\operatorname{trn} \mathrm{W}$ of $A$. aulacocarpa. The arrows show the differences in the band migration between the two PCR products. I-VI denote the SSCP types. Number of each lane according to Table 1. M: Size marker

The smallest mean genetic distances within populations were found in the Wipim District WP (WD), PNG (0.03 \pm 0.01$)$, and Tully-Mission Beach (TB), QLD (0.03 \pm $0.01)$. The highest value was in Kuel (KI), IND $(0.07 \pm 0.012)$ and Gubam Ne Morehead WP $(\mathrm{GM}), \mathrm{PNG}(0.07 \pm 0.030)$. The highest mean genetic distance between populations was recognized between Piru (PS) and Kuel (KI), IND $(0.09 \pm 0.02)$. The mean genetic distances between and within populations were $0.05-0.09(0.07 \pm 0.01)$ and $0.03-0.07$ $(0.06 \pm 0.02)$, respectively, suggesting that there is little difference between the mean genetic distances of inter- and intra- populations, and that there has been no remarkable geographical differentiation in $A$. mangium. 
Table 6. Mean genetic distances within and between the $A$. mangium population

\begin{tabular}{lcccccc}
\hline \multicolumn{1}{c}{ Population } & PS & KI & GM & WD & CR & TB \\
\hline Piru, Seram, IND (PS) & 0.06 & & & & & \\
& $(0.03)$ & & & & & \\
Kuel, Irian Jaya, IND (KI) & 0.09 & 0.07 & & & & \\
& $(0.02)$ & $(0.01)$ & & & & \\
Gubam NE Morehead WP, PNG (GM) & 0.08 & 0.07 & 0.07 & & & \\
& $(0.02)$ & $(0.02)$ & $(0.03)$ & & & \\
Wipim District WP, PNG (WD) & 0.07 & 0.06 & 0.07 & 0.03 & & \\
& $(0.01)$ & $(0.02)$ & $(0.02)$ & $(0.01)$ & & \\
Claudie River, QLD (CR) & 0.07 & 0.08 & 0.07 & 0.06 & 0.06 & \\
& $(0.01)$ & $(0.02)$ & $(0.02)$ & $(0.01)$ & $(0.01)$ & \\
Tully-Mission Beach, QLD (TB) & 0.07 & 0.07 & 0.07 & 0.05 & 0.06 & 0.03 \\
& $(0.01)$ & $(0.02)$ & $(0.02)$ & $(0.01)$ & $(0.01)$ & $(0.01)$ \\
\hline
\end{tabular}

Note: The standard deviation of each genetic distance is given in parenthesis

\section{DISCUSSION}

\section{A. Phylogenetic relationship among the four Acacia species}

Genetic diversity in the Acacia species, especially in A. auriculiformis, A. aulacocarpa, A. crassicarpa, and $A$. mangium, has been evaluated based on molecular data (Moran et al., 1988; Khasa et al., 1993, 1994; Butcher et al., 1998). According to these studies, the four species are closely related, and their ecological characteristics and distribution area are extremely similar, whereas the classification under the subsection level is not yet well understood.

Pettigrew and Watson (1975) have indicated that the section Juliflorae can be classified into three groups based on their numerous morphological characteristics. In this classification, the four species investigated in this study were placed in the same group, suggesting their close relationship. However, using RAPD analysis, which is effective in examining relationships between closely related species, the four species could clearly be separated into two distinct groups (A. auriculiformis and A. mangium, A. aulacocarpa and $A$.crassicarpa). This result indicates that the taxon of Pettigrew and Watson's classification can be subdivided into some lower taxa. In the SSCP of cpDNA, the intergenic spacer between the trn $\mathrm{P}$ and $\operatorname{trn} \mathrm{W}$ genes, a cpDNA haplotype was shared 
between $A$.auriculiformis and $A$. mangium, and another haplotype was shared between $A$. aulacocarpa and $A$. crassicarpa. The chloroplast DNA information supported the phylogenetic relationships revealed by the RAPD analysis.

Inter-specific hybrid between $A$. mangium and $A$. auriculiformis has been found in both natural distribution and also plantation (Awang and Taylor, 1993; Sedgley et al., 1992). Putative natural hybrid between $A$. aulacocarpa and $A$. crassicarpa, and also between $A$. aulacocarpa and $A$. auriculiformis has been reported (Thomson, 1994). These conditions revealed that hybridization and introgression maybe happened among the four Acacia species. By hybridization and introgression, genomic regions of one species can be transferred into the genome of another. If introgression is extensive, genes can move across species boundaries by using hybrid individuals and hybrid populations as bridges for gene flow which can have eventually different consequences. At one extreme, it may cause a merging of the hybridizing species which in turn leads to a decrease in biodiversity (Arnold, 1997).

These results suggest that natural hybridization should be further verified using molecular markers. Molecular markers have proved to be extremely useful in determining whether a species is introgressed with genes from another species (Martinsen et al., 2001).

In Figure 3, it can be seen that the branching in each cluster is essentially different. $A$. auriculiformis and $A$. mangium diverged earlier, and each formed a subcluster, indicating that these two species speciate each other completely. Since both species are closely related and easily hybridize both naturally and artificially, Sedgley et al. (1992) have proposed that the two Acacia species should not be classified as two independent species but as two subspecies of the same species. Khasa et al. (1994) has demonstrated that $A$. auriculiformis can be placed as a direct ancestral species of $A$. mangium based on the results of isozyme analysis. In an artificial cross between the two species, the fertility when $A$. mangium is used as the female parent is higher than that when $A$.auriculiformis is used (Sedgley et al., 1992), possibly suggesting an imperfect reproductive isolation between the species. Although a similar phenomenon has been observed between Pinus densiflora Sieb. et Zucc. and P. thunbergii Parl. distributed in Japan, the phylogenic relationship between these two species is not as close (Watanabe et al., 1996). It seems that $A$. auriculiformis and $A$. mangium are quite different species and that they are not closely related. Boland et al. (1990) have considered $A$. mangium to be an ancestor of the Acacia species. However, the results of Khasa et al. (1994) and this study are in conflict with this hypothesis.

On the other hand, $A$. aulacocarpa and $A$. crassicarpa are closely related. As their distributions overlap on New Guinea Island and in north Queensland, they are hybridized naturally, and they are morphologically similar, Thomson (1994) has pointed out that $A$. crassicarpa should be classified as a subspecies in $A$. aulacocarpa. McDonald and Maslin (2000) reported the closed relationship between $A$. aulacocarpa (that taxonomically 
have been revised into 7 species) and $A$. crassicarpa. Our principal component analysis (Figure $4(\mathrm{~A})$ ) also showed that the genome compositions of both species are similar. The separation between the two species in the dendrogram (Figure 3) is relatively imprecise. In addition, from the molecular information, $A$. crassicarpa should be regarded as a subspecies of $A$. aulacocarpa.

\section{B. Genetic diversities in four Acacia species}

Acacia aulacocarpa has been considered to be a species with high genetic diversity (Thomson, 1994) and has been classified into five subspecies. Four subspecies are distributed in Australia (subspecies A, C, D, E) and the other subspecies (subspecies B) is distributed on New Guinea Island. The results of our DNA analysis, which suggest that $A$. aulacocarpa possesses the highest genetic diversity of the four species examined (Tables 4 and 5), support the previous morphological classification. Of the four subspecies distributed in Australia, three subspecies (subspecies C, D, E) are distributed in QLD. Some of these subspecies are thought to have been contained in the three samples from QLD used in this study. The RAPD data showed high genetic distances among the three samples of $A$. aulacocarpa from QLD. Two types of the cpDNA haplotype were observed in the SSCP analysis of cpDNA. These results suggest the advance of genetic differentiation among QLD subspecies. In addition, a high genetic diversity in $A$. aulacocarpa was also observed between NGI and QLD. The three samples from NGI used in this experiment might have been the $A$. aulacocarpa subspecies B distributed in NGI. The RAPD analysis showed a separation of the samples from the two regions into two different clusters (Figure 3), and as for the cpDNA, different haplotypes were observed between NGI and Australia (Figure 5). In summary, we suggest that the genome compositions between NGI and Australia are distinctly different based on ncDNA and cpDNA information. As New Guinea Island was isolated from the Australian continent relatively early, interfering in the gene flow between the two regions, genetic differentiation between the regions appears to have been promoted. McDonald and Maslin (2000) have done taxonomic revision of $A$. aulacocarpa. The species have revised into 7 species and geographic distribution of those species is related with 5 subspecies revealed in this study. The revision also recognized the high genetic diversity of $A$. aulacocarpa.

Moran et al. (1988) have evaluated the genetic diversity of nine Acacia species distributed from Australia to Papua New Guinea and Indonesia, showing that the heterozygosity of $A$. mangium is extremely low among these species. The same result using isozyme analysis has also been reported by Khasa et al. (1993). Although the RAPD and isozyme markers are distinct, the RAPD in this study gave similar results to those described above. Recently, Butcher et al. (1998) have estimated the genetic diversity of A. mangium using RFLP (restriction fragments length polymorphism) analysis. This estimated value was eight times higher than that obtained from isozyme analysis. They concluded that the number of loci used and the different marker characteristics between 
the isozymes and the RFLPs caused the different results. Certainly, isozyme information is related to the coding regions, whereas RFLP detects variations in the non-coding regions, which are more variable than the coding regions.

A. crassicarpa appears to have a low level of genetic diversity based on the results of the RAPD analysis. This finding corresponds to that obtained from an isozyme analysis reported by Moran et al. $(1988,1989)$. In this study, a cpDNA haplotype polymorphism within species was observed in $A$. aulacocarpa and $A$. auriculiformis, whereas no intraspecific variations were observed in $A$. mangium and $A$. crassicarpa. Although the sample size used in this study was small (six samples for each species), these different molecular markers provided similar results.

\section{Micro-evolutional processes of $A$. mangium and $A$. aulacocarpa}

Acacia species commonly distributed on New Guinea Island and its vicinities were considered to have migrated from the Australian continent. The land bridge connecting northeastern Australia to its vicinal islands in the past played an important role in the migration and radiation of the Acacia species in this region (Moran et al., 1988, 1989; Khasa et al., 1994; Butcher et al., 1998). All four species investigated in this study were distributed in this area. Because of the small sample size used in this study, we must abstain from a more detailed discussion. However, for $A$. aulacocarpa, an appreciable difference was recognized between Australia and NGI. On the other hand, in $A$. mangium, which was investigated using six populations ( 24 individuals), less variation was recognized among populations. These results seem to suggest that $A$. aulacocarpa and $A$. mangium spread at significantly different times. In order to infer in detail the microevolution of the Acacia species from Australia to circumference islands, an accumulation of biogeographic information will be needed in addition to the molecular phylogeny.

\section{CONCLUSSION}

Based on DNA molecular markers, the four Acacia species were divided into 2 groups. $A$. auriculiformis and $A$. mangium formed one group, and the other group comprised $A$. crassicarpa and $A$. aulacocarpa.

The highest genetic diversity between and within species was revealed by $A$. aulacocarpa. However, $A$. mangium showed the lowest genetic diversity.

\section{REFERENCES}

Arnold, M.L. 1997. Natural Hybridization and Evolution. Oxford Series in Ecology and Evolution. New York: Oxford University Press.

Awang, K. and D. Taylor. 1993. Acacia mangium growing and utilization. Winrock International and the Food and Agriculture Organization of The United State Nations. Bangkok, Thailand. 
Bodenes, C., F. Laigret and A. Kremer. 1996. Inheritance and molecular variations of PCR-SSCP fragments in pedunculate oak (Quercus robur L.). Theoretical and Applied Genetics 93: 348-354.

Boland, D.J., K. Pinyopusarerk, M.W. McDonald, T. Jovanovic and T.H. Booth. 1990. The habitat of Acacia auriculiformis and probable factors associated with its distribution. Journal of Tropical Forest Science 3: 159-180.

Boughton, V.H. 1986. Phyllode structure, taxonomy and distribution in some Australian Acacias. Australian Journal of Botany 34: 663-674.

Brain, P. and B.R. Maslin. 1996. A serological investigation of the classification of Acacia subgenus Phyllodineae (Leguminosae: Mimosoideae). Biochemical Systematics and Ecology 24: 379-392.

Butcher, P.A., G.F. Moran and H.D. Perkins. 1998. RFLP diversity in the nuclear genome of Acacia mangium. Heredity 81: 205-213.

Caron, H., S. Dumas, G. Marque, C. Messier, E. Bandou, R.J. Petitand and A. Kremer. 2000. Spatial and temporal distribution of chloroplast DNA polymorphism in a tropical tree species. Molecular Ecology 9:1089-1098.

Chen, J., C.G. Tauer and Y. Huang. 2002. Paternal chloroplast inheritance patterns in pine hybrids detected with $\operatorname{trn} \mathrm{L}-\operatorname{trn} \mathrm{F}$ intergenic region polymorphism. Theoretical and Applied Genetics 104:1307-1311.

Das, A.B., A.K. Mukherjee and P. Das. 2001. Molecular phylogeny of Heritiera Aiton (Sterculiaceae), a tree mangrove: variations in RAPD markers and nuclear DNA content. Botanical Journal of the Linnean Society 136: 221-229.

Harrier, L.A., P.W. Whitty, J.M. Sutherland and J.I. Sprent. 1997. Phenetic investigation of non-nodulating African species of Acacia (Leguminosae) using morphological and molecular markers. Pl. Systematic Evolution 205: 27-51.

Khasa, P.D., W.M. Cheliak and J. Bousquet. 1993. Mating system of Racosperma auriculiforme in a seed production area in Zaire. Canadian Journal of Botany 71: 779-785.

Khasa, P.D., W.M. Cheliak and J. Bousquet. 1994. Genetic variation in 26 populations of Racosperma auriculiforme and Racosperma mangium using allozymes. Canadian Journal of Forest Research 24: 1123-1132.

Martinsen, G.D., T.G. Whitham, R.J. Turek and P. Keim. 2001. Hybrid populations selectively filter gene introgression between species. Evolution 55: 1325-1335.

McDonald, M.W. and B.R. Maslin. 2000. Taxonomy Revision of the Salwood: Acacia aulacocarpa Cunn. ex Benth. and its allies (Leguminosae: Mimosoideae: secion Juliflorae). Australian Systematic Botany 13:21-78. 
Moran, G.F., O. Muona and J.C. Bell. 1988. Acacia mangium: a tropical forest tree of the coastal lowlands with low genetic diversity. Evolution 43: 231-235.

Moran, G.F., O. Muona and J.C. Bell. 1989. Breeding systems and genetic diversity in Acacia auriculiformis and A. crassicarpa. Biotropica 21:250-256.

Narazaki, K., A. Watanabe, K. Tomita, Y. Sasaki and S. Shiraishi. 1996. DNA analysis of the interspecific hybrid clones and the horticultural varieties of Chamaecyparis obtusa and C. pisifera. Journal of the Japanese Forestry Society 78: 157-161.

Orita, M., H. Iwahana, H. Kanazawa, K. Hayashi and T. Sekiya. 1989. Detection of polymorphisms of human DNA by gel electrophoresis as single-strand conformation polymorphisms. Proceedings of the National Academy of Science USA 86: 2766-2770.

Pettigrew, C.J. and L. Watson. 1975. On the classification of Australian Acacias. Australian Journal of Botany 23: 833-847.

Rimbawanto, A., A.Y.P.B.C. Widyatmoko and Harkingto. 2006a. Population diversity of Eusideroxylon zwageri in East Kalimantan revealed by RAPD markers. Jurnal Penelitian Tanaman Hutan 3:201-208.

Rimbawanto, A., A.Y.P.B.C. Widyatmoko and P. Sulistyowati. 2006b. Genetic diversity and its distribution of Santalum album populations revealed by RAPD markers. Jurnal Penelitian Tanaman Hutan 3:175-181

Rimbawanto, A. and A.Y.P.B.C. Widyatmoko. 2006. Genetic diversity of four populations of Intsia bijuga revealed by RAPD markers and its implications for the genetic diversity conservation programme. Jurnal Penelitian Tanaman Hutan $3: 149-154$.

Ross, J.H. 1981. An analysis of the African Acacia species: their distribution, possible origins and relationships. Bothalia 13: 389-413.

Sedgley, M., J. Harbard, R-M. Smith, R. Wickneswari and A.R. Griffin. 1992. Reproductive biology and interspecific hybridization of Acacia mangium and A. auricuriformis A. Cunn. ex Benth. (Leguminosae: Mimosoideae). Australian Journal of Botany 40: 37-48.

Shiraishi, S., H. Maeda, T. Toda, K. Seido and Y. Sasaki. 2001. Incomplete paternal inheritance of chloroplast DNA recognized in Chamaecyparis obtusa using an intraspecific polymorphism of the trn D-trn $\mathrm{Y}$ intergenic spacer region. Theoretical and Applied Genetics 102: 935-941.

Shiraishi, S. and A. Watanabe. 1995. Identification of chloroplast genome between Pinus densiflora Sieb. et Zucc. and P. thunbergii Parl. based on the polymorphism in $r b c \mathrm{~L}$ gene. Journal of the Japanese Forestry Society 77: 429-436. 
Shiraishi, S., K. Isoda, A. Watanabe and H. Kawasaki. 1996. DNA systematical study on the Larix relicted at Mt. Manokami, the Zao Mountains. Journal of the Japanese Forestry Society 78: 175-182.

Sokal, R.R. and C.D. Michener. 1958. A statistical method for evaluating systematic relationships. The University of Kansas Science Bulletin 38: 1409-1438.

Thomson, L.A.J. 1994. Acacia aulacocarpa, A. cincinnata, A. crassicarpa and A. wetarensis: an annotated bibliography. Division of Forestry, Australian Tree Seed Centre, Canberra. 131pp.

Wang, J.L., N.X. Zhao, Y.B. Gao, F. Lin, A.Z. Ren, W.B. Ruan and L. Chen. 2006. RAPD Analysis of Genetic Diversity and Population Genetic Structure of Stipa krylovii Reshov. in Inner Mongolia Steppe. Russian Journal of Genetics 42: 468-475.

Watanabe, A., Shiraishi, S., Kawase, E., Toda, T. and Nasu, T. 1996. Genome analysis of Pinus $\mathrm{x}$ densi-thunbergii Uyeki using DNA molecular markers. - Verification of its hybridity -. si-thunbergii Uyeki using DNA molecular markers. - Verification of its hybridity -. 78: 293-300.

Watanabe, A., H. Maeda and S. Shiraishi. 1997. A simple identification of chloroplast genome types between Pinus densiflora Sieb et Zucc. and P. thunbergii Parl. using PCR-SSCP Analysis. si-thunbergii Uyeki using DNA molecular markers. Verification of its hybridity -. 79: 155-156.

Wickneswari, R. and M. Norwati. 1993. Genetic diversity of natural populations of Acacia auriculiformis. Australian Journal of Botany 41: 65-77.

Williams, J.G.K., A.R. Kubelic, K.J. Livak, J.A. Rafalski and S.V. Tingey. 1990. DNA polymorphisms amplified by arbitrary primers are useful as genetic markers. Nucleic Acids Research 18: 6531-6535. 